\author{
Alberto Bernini \\ ADAFA Association, Italy
}

\title{
THEORETICAL FRAMEWORKS FOR A PERSON- ORIENTED APPROACH TO MULTILINGUALISM: THE CASE OF SOUTH TYROLEAN SCHÜTZEN
}

\begin{abstract}
Summary. Starting with the cultural standardisation due to the phenomenon of globalisation, which has led to the liquid modernity, the article suggests some proposals for an approach more respectful of the cultural and linguistic rights of both people and communities. A person-oriented approach appears to be the best solution to guarantee linguistic and cultural diversity. The article presents a case study of the South Tyrolean Schützen that can be considered as a concrete example of a person-oriented philosophy as demonstrated by their engagement in the defence of local identity through the centuries. Born as a territorial militia in the Modern Age, they reacted to the ideology of the Enlightenment and to the French Revolution because they rejected the principles at the basis of the nation-state. Nowadays they oppose to globalisation and cultural levelling. The article resorts to theoretical frameworks pertaining to (1) sociology, i.e., Putnam's social capital that centres on the civic values of trust and solidarity, (2) linguistics, i.e., the ethno-linguistic approach that focuses on cultural aspects of language and (3) philosophy, i.e., the critique of the nation-state model and the idiofobia (i.e., the 'fear of different identities'). These topics emerge from the analysis of the activities of the Schützen, thus proposing them as a model suitable for contemporary society. According to their philosophy, preservation of cultural diversity is not limited to cultural aspects, but involves a broad topic, namely the person and the community conceived as two distinct subjects, and at the same time necessary for a rights-oriented, multicultural, and multilingual society.
\end{abstract}

Keywords: globalisation, language policy, nation-state, social capital, local identity, language as culture, idiofobia, Schützen.

\section{Introduction}

In today's globalized world which is characterised by general cultural levelling safeguarding local identities means both implementing democracy and respecting individual rights. Among these rights, an important position is held by cultural rights and in particular by linguistic ones. Most of the current language policies (I refer especially to those typical of the nation-states) are aimed at spreading the 'powerful' languages to the detriment of the 'weak' languages which have been increasingly marginalized.

By resorting to theoretical frameworks that imply an anthropocentric view, this article focuses on a concrete example of preservation of cultural and 
linguistic identity and aims at demonstrating that such a view can be put into practice also in the contemporary world. In fact, unlike the language policies of many European countries, characterised by the pre-eminence of the institutional needs, in the Italian autonomous province of South Tyrol we find the case of the Schützen (the defenders of the South Tyrolean identity), whose philosophy is based on the concept of person and community. Through their social activities, they contribute to defend traditional cultural diversity, thus offering a real example of sustainable cultural pluralism and multilingualism.

\section{Methodology and research limitations}

The article employs a double approach, characterised by the analysis of the adopted theories (which belong to the sociological, anthropological and linguistic fields), and the examination of a particular case study (see Cipolla, 1996) of the Schützen. As far as social capital is concerned, various case studies have been analysed in the last years, on the basis of approaches that are highly different: there are historical analyses (Greene, 1999), economic studies (Torres Vitolas, 2011) and theoretical studies (Mungal, 2004). The present article combines theoretical and empirical approaches. The research is conducted according to the epistemological model that represents the basis for sociological analysis.

Starting with the problems and the opportunities deriving from today's liquid society, the article is based on the following theoretical frameworks:

1. The critique to the nation-state model;

2. The social capital;

3. The cultural value of the language;

4. The idiofobia (i.e., the 'fear of different identities').

Although these trends pertain to different fields, they are directed towards a single aim, i.e., the focus on identity in relation to both individuals and communities. The attention paid to linguistic, cultural and social aspects leads to a proposal that, thanks to its interdisciplinarity, can adequately represent a feasible model for fostering multilingualism in contemporary society. The research limitations rest in the choice of the frameworks since several scholarly 
Alberto BERNINI

approaches to social capital as well as to multilingualism and multiculturalism have been proposed (in particular regarding the value of the language beyond its instrumental usages). This article chooses the linguistic framework that focuses on the cultural and social values of languages (Duranti, 2001; Michael, 2011) and Putnam's (2000) social capital, because they share a clear anthropocentric view, without resorting to ideological approaches. Together with the other frameworks, they concern the demo-ethno-anthropological context and consider cultural heritage as the premise for implementing individual rights and the civic sense. Future developments may consist of the comparison between the Schützen and other similar case studies within the European context.

\section{The global context: liquid modernity}

One of the most thorough analysis of contemporary society is carried out by Bauman (2000; 2003) who coined the expression 'liquid modernity' in order to identify the transnational world in which the borders (both concrete and abstract) tend to disappear. The relation between people and society changes regarding the concept of citizenship that assumes the feature of a series of fluid (or 'liquid') bonds based on overcoming more traditional social structures. One of the most evident features of this society is the loss of the importance of the nation-states as well as other landmarks (such as ideologies, political parties, religion, etc.) in favour of supra-national powers. This fact has caused the process of civic deconstruction that has resulted in the abandonment of the old social structure with the consequent creation of a global society in which the individualistic view is more important than common cultural heritage, and life, undermined by a widespread sense of uncertainty, is shaped by the motto hic et nunc (Bauman, 2000, pp. 160-162).

From this viewpoint, liquid modernity is undoubtedly harmful to cultural plurality, favouring the overwhelming spread of English in place of 'weaker' 
languages ${ }^{5}$. However, this phenomenon may be an unintentional chance for safeguarding local identities, because it weakens the importance of the nationstates (and consequently of their language policies) that have traditionally tried to flatten local languages and identities ${ }^{6}$. According to this perspective, the concepts of language and dialect relate to the principles of nation and community and recall the division already proposed by Tönnies (2011), who discussed the new aspects of industrialisation asserting that after the Industrial Revolution the community of persons was substituted by the society of individuals, thus causing social fragmentation and the loss of the old certainties in favour of the modern state. Changes during the last two centuries have led to a society characterised by the individualistic essence instead of the concept of personal solidarity which is basic for maintaining the social structure of the local community.

\section{Theoretical frameworks in favour of local identities}

\section{Modern state as a religion}

Since the French Revolution, the legitimisation of power in Europe has been based on the principle lingua instrumentum regni (i.e., "language is the instrument of political control") that has replaced the principle religio instrumentum regni (i.e., "religion is the instrument of political control"). According to this political system, on the one hand, citizens are equal and their rights are defended regardless of their social class, religion and attitudes; but, on the other hand, they must adhere to the culture (and in primis the language) spread through top-down processes by the centralised state. During the Ancien Régime religion was exploited by the rulers to legitimise their power; now this role is played by national cultures, because a nation binds together different

\footnotetext{
${ }^{5}$ For an overview on linguistic imperialism, see e.g., Phillipson and Skutnabb-Kangas (2013).

${ }^{6}$ As witnessed, after the Fall of the Berlin Wall, by a more and more active engagement of movements requesting more autonomy and preservation of cultural heritage at local level (Dell'Aquila and Iannàccaro, 2004, pp. 44-47).
} 
people who must have a single culture, history and language. The national language becomes the symbol of the nation, and requires standardisation in order to be easily understood by all citizens: through language policies, nationstates establish a common phonology, orthography and vocabulary. The main instrument for carrying out the pre-eminence of the national language is the school (Dell'Aquila, Iannàccaro, 2004, pp. 29-32).

In this way, the concept of a state is connected with the growth of the centralised power that sets at upper levels the rules of conduct for all citizens. The opposition between the old state and the modern state clearly emerges from the analysis of their essence: the monarchical institution has a personal trait, while the nation-state has a functional aim. The former is related to the individual responsibilities of the monarch for his own resolutions, whereas the latter is founded on the bond between institution and people (who must recognize it as sovereign).

Two features of the nation-state act against an anthropocentric view of society, by more and more widely spreading the state influence in society. The first one is the reduction of the importance of private law in favour of public law: the former is evolutionary and customary, while the latter is arbitrary and artificial. The second one is the adoption of the most important features of religious tradition as to become the nation-state itself a new civic religion characterised by the absolute faith in its institutions, conceived as a sort of a modern object of veneration. It has developed the principle of political theology, characterised by the reliance on the secularised society after the decrease of the religious sentiment (a condition that very closely resembles the current trend of the western world). By marginalising religion, which entails the personal comparison between the believer and the religious principles, it proposes itself as the only social system able to guarantee the civic development through the constitution of a bureaucratic class that substitutes the previous religious order. The concept of citizenship is an example of faith in the state, since belonging to this institution implies complete acceptances of the civic law and the consequent rejection of the religious principles of the community that are exclusively restricted to the individual sphere (Lottieri, 2011, pp. 9-31). The critique of a 
modern state as civic religion is very well summarized by Lottieri, who asserts that:

"[t]ra l'ordine politico «religioso» di un monastero liberamente scelto dai propri membri, e da cui si possa in ogni momento uscire, e l'ordine politico «laico» di una realtà a-confessionale imposta ai propri membri, un libertario non ha dubbi nel preferire il primo tipo di istituzione" (ibid., p. 31) ${ }^{7}$.

\section{Social capital and language}

The expression 'social capital' was coined in 1916 by the American sociologist Lyda Hanifan in order to identify the social connections that are at the basis of society. Since the 1960s it has occupied a key position in the field of sociology. According to Andreotti (2009, pp. 7-28), four major trends of social capital can be distinguished:

1. Economic (Bourdieu) - social capital is a product of civic relations for reducing economic inequalities;

2. Social resources (Nan Lin) - the relevance of social development is connected with the ability to create social grids for implementing the civic growth;

3. Micro-sociology (Coleman) - social capital is a civic bridge between the economy and society that creates social bonds among citizens;

4. Social union (Putnam) - social capital is a tool for implementing civic aggregation and for developing the state through the cooperation of its citizens. By ranging over the cultural, economic and social fields, Putnam's research (which is considered significant for the present article) stresses the importance of trust and solidarity in creating civic cooperation that in turn represents an opportunity for the development of the community. He defines social capital in this way: "[t]he concept of social capital is referred to the civic network, defined social, that establish the level of development, through interpersonal

\footnotetext{
7 'Between the 'religious' political order of a freely chosen monastery, from which one can leave anytime, and the 'secular' political order of a non-denominational entity imposed to its members, a libertarian prefers the first institution'.
} 
relationships founded on trust and solidarity" (Putnam, 2000). His approach focuses on the civic effects of social capital with particular reference to the development of deliberative democracy through civic bonds that in turn leads to the participation of citizens in public life, to social cohesion and to the sense of belonging. From this viewpoint, the topic of language is significant because it favours solidarity among members of a (cultural) community, thus both guaranteeing the civic cohesion at local level and strengthening the demoethno-anthropological structure, that is to say, the local cultural heritage (Andreotti, 2009, pp. 44-60). This idea is shared also by Nahapiet and Ghoshal (1998, pp. 253-254) who assert the importance of the shared language to be relevant for social capital because language has a direct and social function in public relations and influences our perception of the real facts.

The bond between language and social capital relates to the development of the public good through the preservation of cultural heritage thanks to the creation of free associations. The defence of local heritage (both material and immaterial) plays a key role in the protection of the history and for retaining the communitarian memory, thus strengthening the common sense of belonging. Moreover, cultural heritage helps enterprises in developing economic growth through the creation of social bonds that also favour the democratic expansion of society. In this way, the civic cohesion takes part in the cultural panorama and gets into public debate referred to through the concept of membership in a social group characterised by common features. This condition is the main requirement for the constitution of social cohesion characterised by the high level of trust and solidarity among neighbours, through the common aims and the awareness that collectivity needs unity of purpose.

\section{Beyond the communicative function: language as culture}

In addition to its communicative functions ${ }^{8}$, language is an important identity

\footnotetext{
${ }^{8}$ Even the instrumentalist approach supports the idea that linguistic diversity can help in preserving cultural diversity (see Robichaud and De Schutter, 2012, p. 137). However, the
} 
marker and, according to the anthropological view, a non-neutral medium that can be interpreted as (Duranti, 2011):

1. A code for representing experience: "by linguistically encoding human experience, speakers submit to particular ways of categorizing and conceptualizing the world" (ibid., p. 30);

2. A form of social organization: "language is not only a way of encoding knowledge but also a way of acting in the world" (ibid., p. 38);

3. A system of differentiation: "language varieties are used to perform certain social activities including the expression of solidarity and the communication of the perceived status of one's interlocutor" (ibid., p. 43).

In particular, language is connected with the concept of habit in relation to the community, because the code used by members of a group demonstrates that the importance of the language concerns not only the purely communicative aspects, but also the 'immaterial' identity, so as to recognize that the community is shaped by its cultural features. As summarised by Duranti (ibid., p. 46), a language is "a tool that plays a role in the ways in which speakers think and act as well as in the way an activity is socially organized" ${ }^{\prime 9}$. The person and the community are not two separate subjects, but two sides of the same coin.

Language and culture are correlated and represent the basis on which social system is found through the preservation of the popular identity and by the constitution of a linguistic code that is able to guarantee both the cultural development and the defence of the common cultural heritage. Thus, language shift implies a real cultural loss ${ }^{10}$.

Two features are common to the various existing definitions of culture:

1. "Culture is a learned body of behaviours and/or knowledge transmitted by trans-generational learning";

trends that study the cultural value of a language should not disregard the results achieved by generative linguists (Rizzi, 2014, pp. 28-30).

${ }^{9}$ At the same time language can be an instrument of exclusion that is one of the reasons why only through multilingualism can we preserve a multicultural society.

${ }^{10}$ UNESCO (2003) considers language as a "vehicle of the intangible cultural heritage". 
Alberto BERNINI

2. "This body is predicated primarily of human groups and, only through membership in a group, of individuals" (Michael, 2011, p. 121).

These points refer to communitarian and individual aspects within a broader sociological frameworks, in fact, "the study of language and culture involves a focus on those aspects of social practices in which linguistic form and social action play important mutually constitutive roles, especially those that by virtue of their variability across human groups are seen as cultural in nature" (ibid.,

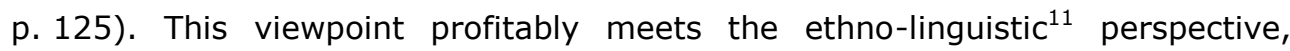
according to which language is the tool through which culture nourishes people, and culture is the whole of knowledge transmitted by the trans-generational learning, through the awareness that the preservation of the collective memory is one of the main aims of the community (ibid., pp. 121-140).

\section{Behind the cultural impoverishment: idiofobia}

In the last decades the concept of identity has decreased its importance within society because of the demise of the certainties that have characterised civic life until the recent past. This phenomenon, which is manifested on a global scale, has led to social disintegration and to the contraposition between the ego and the other. The loss of identity in particular has created basis for the civic fragmentation, evident in the difficulty of communication among citizens that are more and more separated in their 'lonely life'. This situation resulted in the split of identity in different parts divided in many elements and lacking the sense of unity, because the loss of cohesion is at the basis of their essence. The more identity is perceived as a founding element of the person, the more society is cohesive, but when society loses such cohesion, it makes real steps to social disintegration.

The concept of identity, created by a synthesis between thesis and antithesis, represents the element of social cohesion par excellence, and confers

\footnotetext{
11 A thriving research field, including several approaches, such as ethnography of communication, ethno-pragmatics, ethno-semantics, ethno-syntax, linguistic relativity (Michael, 2011).
} 
on reality its particular features. Identity becomes relevant to the constitution of a democratic society as an element characterising one's own autonomy that in turn generates the social cohesion of the community. The loss of certainties in many societal fields (typical of liquid modernity) has led to a general sense of bewilderment and to the social landscape characterised by the decrease of the civic cohesion to the advantage of the loss of those certainties that in the past were at the basis of everyday life. Such phenomena imply the loss of the concept of identity: a condition that can be defined as idiofobia (Bernini, 2014, p. 109).

\section{Safeguarding local identities: South Tyrolean Schützen}

\section{The Südtiroler Schützenbund}

An important example for the preservation of the common cultural heritage can be found in Northern Italy, more precisely, in the province of Bolzano/Bozen, where the association Südtiroler Schützenbund is located. Its members, the Schützen, are present in the whole Tyrol (a historical region across Italy and Austria), but are particularly active in this province, representing a longstanding model of non-institutional local autonomy. Nowadays, their aim is the preservation of the South Tyrolean traditions, common heritage, collective memory, language, various groups devoted to social activities (for an overview, see Bernini, 2013, pp. 27-28). Their philosophy is well summarised by their motto: 'Glaube, Heimat, Vaterland' (i.e., 'faith, homeland, fatherland').

\section{Defence of local autonomy and culture}

A territorial militia was present in Tyrol since the Middle Ages ( $13^{\text {th }}-14^{\text {th }}$ cent.), but the Schützen as local army were founded officially in 1511, when the promulgation of the Tiroler Landlibell established the permanent conscription. 
The first considerable military involvement took place in $1796^{12}$ against Napoleon's troops: the fight against the French army was both a military and a cultural fight, since they defended their traditional society against the idea of non-denominational state and secular society spread by the Enlightenment and the French Revolution. During the First World War they fought against Italy, but the defeat of the Austro-German alliance resulted in the annexation of South Tyrol by Italy. The nationalistic policy of the Italian state imposed the extensive Italianisation on South Tyrol with subsequent dissolution of the Schützen companies. Only after the Second World War were they reconstituted as a cultural association, but their engagement in favour of local autonomy and identity had not decreased. The new provincial statute promulgated in 1972 gave to the region a considerable autonomy, thus making it easier to defend local identities (Von Hye, 2002).

\section{Social capital and Schützen}

The Schützen reject the basic idea of a nation-state that entails the constitution of a positivist ideology in contrast to the principles of the natural law. Their activities rely on the creation of social capital in so far as the civic cohesion is guaranteed through the constitution of bonds among citizens, characterised by a high level of trust and solidarity that represent the basis on which a local deliberative democracy is established, in contrast to the nationalist principle that favours the needs of a state.

Although they are a cultural association, they maintain the original military division, and are divided into Kompanien ('companies'), Bezirken ('districts'), and Bataillonen ('battalions') (see table 1); every company has a commander and is subordinated to the regional command in Bozen that organises the activities for all the companies and manages the relations with political institutions. The most consistent group is represented by Schützen (adult men), but Marketenderinnen (women, literally 'vivandières'),

\footnotetext{
${ }^{12}$ In the same year, each company was given the name of the respective town, thus strengthening the sense of belonging to the land.
} 
Jungschützen and Jungmarketenderinnen (young members) also play an important role (see table 2). As shown by the tables, the presence of the Schützen is not restricted to some areas; they are homogeneously present in South Tyrol. Moreover, the number of members indicates how they took roots in South Tyrolean society, showing a general growth, in particular of the Marketenderinnen.

Table $1^{13}$

\section{Division of the Schützen in 2015}

\begin{tabular}{|c|c|c|c|c|c|}
\hline \multicolumn{3}{|c|}{ District } & \multicolumn{3}{|c|}{ Battailons } \\
\hline Place & Companies & Members & Name & Companies & Members \\
\hline $\begin{array}{c}\text { Burggrafenamt/ } \\
\text { Passeier }\end{array}$ & 26 & 1010 & $\begin{array}{c}\text { Josef } \\
\text { Stecher }\end{array}$ & 9 & 300 \\
\hline Vinschgau & 20 & 650 & $\begin{array}{l}\text { Martin } \\
\text { Teimer }\end{array}$ & 11 & 355 \\
\hline Bozen & 25 & 764 & $\begin{array}{l}\text { Christoph } \\
\text { Casagrande }\end{array}$ & 5 & 180 \\
\hline $\begin{array}{l}\text { Süd-Tiroler } \\
\text { Unterland }\end{array}$ & $\begin{array}{c}12+1 \\
\text { Schützenkapelle }\end{array}$ & 410 & $\begin{array}{l}\text { Martin } \\
\text { Tutzer }\end{array}$ & 7 & 142 \\
\hline Brixen & $\begin{array}{c}19+1 \\
\text { Schützenkapelle }\end{array}$ & 800 & $\begin{array}{c}\text { Hubert } \\
\text { Obgrießer }\end{array}$ & 5 & 207 \\
\hline $\begin{array}{l}\text { Südliches } \\
\text { Wipptal }\end{array}$ & 6 & 142 & & & \\
\hline Pustertal & $\begin{array}{c}33+1 \\
\text { Schützenkapelle }\end{array}$ & 1261 & & & \\
\hline
\end{tabular}

Table $2^{14}$

Men, women and young members between 2007 and 2010

\begin{tabular}{|c|c|c|c|c|}
\hline Year & $\mathbf{2 0 0 7}$ & $\mathbf{2 0 0 8}$ & $\mathbf{2 0 0 9}$ & $\mathbf{2 0 1 0}$ \\
\hline Schützen & 3825 & 3868 & 4023 & 4033 \\
\hline Marketenderinnen & 568 & 604 & 641 & 672 \\
\hline $\begin{array}{c}\text { Jungschützen and } \\
\text { Jungmarketenderinnen }\end{array}$ & 419 & 431 & 462 & 423 \\
\hline
\end{tabular}

\footnotetext{
${ }^{13}$ Seehttp://www.schuetzen.com/ssb/organisation/bezirke.html and http://www.schuetzen.com/ssb/organisation/bataillone.html.

${ }^{14}$ See http://www.schuetzen.com/ssb/nuetzliches/statistik.html.
} 
The public activities in which they take part consist of demonstrations, dances, summer camps for young people and celebrations ${ }^{15}$. They regulate the education of young components and prepare members of the companies for community needs. Their civic commitment is not limited to such activities, but they also play an active role in various social issues: protect the demo-ethno-anthropological structure, do charity, and educate new generations to solidarity. A concrete example is the non-profit organization Herz-Jesu-Notfonds ${ }^{16}$ ('Heart of Jesus emergency fund') that helps the Schützen families in a difficult situation.

\section{Preservation of language and culture}

Their efforts in defence of the local culture essentially consist of the preservation of ${ }^{17}$ :

1. Language and local culture;

2. Traditional clothing and usage;

3. Traditional religious and non-religious celebrations.

The language used during their celebrations and activities is German ${ }^{18}$. This point is relevant in relation to the historical events of the last century: after the First World War, South Tyrol was involved in a programme of forced Italianisation that implied the spread of the Italian language and the Italianisation of toponyms. The situation changed after the Second World War, with the promulgation of the first statute of autonomy (1948), and even more with the second statute (1972). Although regional multilingualism is protected

\footnotetext{
${ }^{15}$ http://www.schuetzen.com/ssb/organisation/organe-des-ssb.html.

${ }^{16}$ http://hjnf.schuetzen.com/.

17 http://podcasting.provinz.bz.it/cultura/podcast.php?cat=CapitaleSociale_Sozialkapital. ${ }_{18}$ Only occasionally Italian can be used, see e.g., http://altoadige.gelocal.it/bolzano/cronaca/2015/04/18/news/grande-guerrakompatscher-depotenzia-gli-schutzen-occhio-al-nazionalismo-1.11259947.
} 
by law, their efforts are very important for protecting the German language ${ }^{19}$ in a non-German-speaking country ${ }^{20}$.

In this way, the proposed multilingualism is constructive, as witnessed by the trilingual landscape of the South Tyrol, where the multilingualism is not limited to German and Italian but also Ladin (e.g., Bernini, 2013); and the Schützen themselves support the protection of Ladin identity ${ }^{21}$. Preservation of local culture is evident not only in the defence of the language, but also in the participation in local cultural activities and social events, during which every group (men, women and young people) has its own traditional clothing. Among the non-religious festivities, the anniversary of Andreas Hofer's death (20.02.1810) is particularly important: he was the most famous South Tyrolean patriot who fought against the Enlightenment ideology (supported by the Habsburg monarchy) in order to preserve the Tyrolean autonomy. As far as religious celebrations are concerned, the most important is the Herz-Jesu-Fest that commemorates the alliance between God and man, to be defended from enemies. In the past such enemies were the Enlightenment and Napoleon's army, while today they are the fragmentation of society and the decrease of the religious sense.

\section{Opposition to the idiofobia}

As seen in the activities carried out by the Schützen, not only language and culture, but also history, traditional customs and clothing, improve the identities of communities and their members. Rejection of the centralised nationalism as well as of the levelling force of globalisation and the support to local autonomies and to deliberative democracy concur with the rejection of the 'idiophobic' view of a large part of our society. The concept of 'identity' in turn represents the

\footnotetext{
19 If an objection on this point can be raised, more attention should be paid to the preservation of the local dialects (Bernini, 2013, pp. 27-28); but the choice of German language is likely to be due to the necessity of adopting a Dachsprache.

20 The news about South Tyrolean culture and events are published in the newspaper Tiroler Schützenzeitung (http://www.schuetzen.com/zeitung.html).

${ }_{21}$ See e.g., http://www.schuetzen.com/aktuellbericht/datum/2011/10/15/artikel/treffender-landeskommandanten-im-museum-ladin-458.html.
} 
ground for civic cohesion and the stance against the disintegration and the standardisation of society. As far as language policy is concerned, defending linguistic diversity at local level is closely related to the development of the deliberative democracy. According to the anthropocentric view, institutions (nation-states as well as supra-national entities) are not the cornerstone of the society, but identity per se.

\section{Conclusions}

Though our society asserts to protect human rights (including the respect of cultural differences), cultural identities are not infrequently disregarded or even opposed. This situation is due to the common opinion according to which 'big' cultures better fit the needs of globalisation than 'small' cultures, generally considered as outdated. The dichotomy global/local is thought to be equal to the dichotomy open/closed, thus favouring the decrease of local identities to the advantage of cultural levelling (already caused by the nation-state policies). The Schützen represent a suitable model against these phenomena, since in their philosophy the following concepts are present:

1. Defence of the community:

- safeguarding local identity against the nation-state model;

- civic engagement entailing the dialogue with institutions and social aid;

2. Defence of the person (both as an individual and as a part of the community):

- defence of local language and culture;

- efforts against cultural levelling;

- efforts against idiofobia.

These concepts share a common feature: the anthropocentric view. Only a person-oriented approach can be rightly regarded as a rights-oriented approach, because opposing to the 'idiophobic' forces of liquid modernity and nation-states means safeguarding the cultural freedom of a person that results in a protection of local communities not limited to institutional aspects, but 
involving also the cultural ones. Among these, language occupies the main position, being at the same time culture and a vehicle of culture. A concrete proposal for sustainable multilingualism should not be limited to linguistic aspects, but should suggest a new relation of people/institutions suitable for contemporary society. Nowadays much attention is paid to the topic of multiculturalism, but good intentions are not always put into practice, and without concrete proposals the linguistic landscape will inexorably tend to uniformity.

\section{References}

Andreotti, A. (2009). Che cos'è il capital sociale. Roma: Carocci.

Bauman, Z. (2000). Liquid modernity. Cambridge: Polity Press.

Bauman, Z. (2003). Intervista sull'identità (ed. by B. Vecchi, It. transl. by F. Galimberti). Roma-Bari: Laterza.

Bernini, A. (2013). Globalization and language policy within the EU: a proposal for the South Tyrol. Darnioji Daugiakalbystè/Sustainable Multilingualism, 3, pp. 19-30. DOI: http://dx.doi.org/10.7220/2335-2027.3.3.

Bernini, A. (2014). Capitale sociale e democrazia deliberativa sociale. Cremona: Fantigrafica.

Cipolla, C. (1996). Teoria della metodologia sociologica: una metodologia integrata per la ricerca sociale. Milano: Franco Angeli.

Dell'Aquila, V., \& Iannàccaro, G. (2004). La pianificazione linguistica. Roma: Carocci.

Duranti, A. (2011). Linguistic anthropology: The study of language as a nonneutral medium. In R. Mesthrie (Ed.) The Cambridge handbook of sociolinguistics (pp. 28-46). Cambridge, MA: Cambridge University Press.

Greene, J. P. (1999). History social and cultural capital in colonial British America: A Case Study, The Journal of Interdisciplinary History, 29 (3), pp. 491-509. 
Lottieri, C. (2011). Credere nello stato? Teologia politica e dissimulazione da Filippo il Bello a Wikileaks. Soveria Mannelli: Rubbettino Editore.

Michael, L. (2011). Language and culture. In P. K. Austin and J. Sallabank (Eds.) The Cambridge handbook of endangered languages (pp. 121-140). Cambridge: Cambridge University Press.

Mungal, S. (2004). When social capital doesn't impact political participation: a case study in social capital theory in El Salvador. Retrieved from: http://www.scu.edu/ethics/publications/submitted/mungal/socialcapital-theory.html.

Nahapiet, J., \& Ghoshal, S. (1998). Capital, intellectual capital, and the organizational advantage. The Academy of Management Review, 23 (2), pp. 242-266.

Phillipson, R., \& Skutnabb-Kangas, T. (2013). Linguistic imperialism and endangered languages. In T. K. Bhatia \& W. C. Ritchie (Eds.), Handbook of bilingualism and multilingualism ( $\left.2^{\text {nd }} \mathrm{Ed}.\right)$. (pp. 495-516). Chichester, UK: John Wiley \& Sons.

Putnam, R. D. (2000). Bowling alone. The collapse and revival of American community. New York: Simon and Schuster.

Rizzi, L. (2014). On the elements of syntactic variation. In M. Carme Picallo (Ed.) Linguistic variation in the minimalist framework (pp. 13-35). Oxford: Oxford University Press.

Robichaud, D., \& De Schutter, H. (2012). Language is just a tool! On the instrumentalist approach to language. In B. Spolsky (Ed.) The Cambridge handbook of language policy (pp. 124-145). Cambridge: Cambridge University Press.

Tönnies, F. (2011). Comunità e società (ed. by M. Ricciardi, It. transl. by G. Giordano). Roma-Bari: Laterza.

Torres Vitolas, C. A. (2011). Social capital in poor communities: a case study from rural northern Peru. PhD thesis, The London School of Economics and Political Science (LSE). Retrieved from: http://etheses.Ise.ac.uk/268/1/PhD\%20Thesis\%20Carlos\%20A\%20Torr es\%20Vitolas.pdf. 
UNESCO (2003). Convention for the safeguarding of intangible cultural heritage. Proceedings of the $32^{\text {nd }}$ General Conference of UNESCO, Paris, 29 September - 17 October. Retrieved from:

http://www.unesco.org/culture/ich/en/convention.

Von Hye, F. H. (2002). Gli Schützen tirolesi e trentini e la loro storia. Bolzano:

Athesia.

\section{Webliography}

http://altoadige.gelocal.it/bolzano/cronaca/2015/04/18/news/grande-guerrakompatscher-depotenzia-gli-schutzen-occhio-al-nazionalismo-

1.11259947

http://hjnf.schuetzen.com/

http://podcasting.provinz.bz.it/cultura/podcast.php?cat=CapitaleSociale_Sozialk apital

http://www.schuetzen.com/ssb/nuetzliches/statistik.html

http://www.schuetzen.com/ssb/organisation/organe-des-ssb.html

http://www.schuetzen.com/zeitung.html

\section{Alberto Bernini}

ADAFA asociacija, Italija; famber3@virgilio.it

\section{ASMENI ORIENTUOTO POŽIŪRIO İ DAUGIAKALBYSTE TEORINIAI ASPEKTAI: PIETU TIROLIO SCHÜTZEN ATVEJIS}

Santrauka. Straipsnyje pateikiami keli pasiūlymai kaip suformuoti pagarbesni požiūri i kultūrines ir kalbines žmoniu ir bendruomeniu teises, atsižvelgiant i kultūrinès standartizacijos bei likvidaus modernumo susikūrimo procesus globalizacijos kontekste. I asmeni orientuotas požiūris yra geriausias sprendimas užtikrinant lingvistinę ir kultūrinę ¡vairovę. Straipsnyje pateikiamas Pietu Tirolio Schützen atvejis, kuri galima traktuoti kaip konkretu i asmeni orientuotos filosofijos pavyzdi - šimtmečius trunkanti vietinio identiteto gynimo procesa. Moderniajame amžiuje susiformavę teritorinès sukarintos grupès priešinosi Šviečiamojo amžiaus bei Prancūzijos revoliucijos ideologijai, atmesdami esminius tautos-valstybès principus. Šiais laikais jie prieštarauja globalizacijai ir kultūrinei lygiavai. Straipsnyje nagrinejami teoriniai metmenys, susiję su (1) sociologija, t.y. R. Putnamo socialinio kapitalo koncepcija, nukreipta i pilietines pasitikejjimo ir solidarumo vertybes, (2) lingvistika, t. y. etno-lingvistiniu požiūriu i kultūrinius kalbos aspektus ir (3) filosofija, t. y. tautos-valstybès modelio kritika ir idiofobija („ivairiu identitetu baimè"). Šie klausimai 


\section{Alberto BERNINI}

iškyla analizuojant Schützen veikla, tuo būdu siūlant juos kaip šiuolaikinès visuomenès modeli. Pagal šią teorija kultūrinès ivairovès išsaugojimas neapsiriboja kultūriniais aspektais, o apima plačia problemą - asmens ir bendruomenès suvokimą kaip du atskirus subjektus ir tuo pačiu kaip būtinus elementus, kuriant daugiakultūrinę, daugiakalbę ir i žmogaus teisiu apsauga orientuotą visuomenę.

Pagrindinès sąvokos: likvidus modernumas, globalizacija, kalbu politika, tautavalstybè, socialinis kapitalas, vietinis identitetas, kalba kaip kultūra, idiofobija, Schützen. 